\title{
CHEMISTRY AND SURFACE MICROMORPHOLOGY OF THE QUEENSLAND SUNDEWS (DROSERA SECTION PROLIFERA)
}

JAN SCHLAUER • Zwischenstr. 11 • D-60594 Frankfurt/Main • Germany • jan@carnivorousplants.org Siegfried R. H. HaRTMEYer ANd IRMgard HartMeyer • Wittlinger Str. 5 • D-79576 Weil am Rhein•Germany・s.hartmeyer@t-online.de

Keywords: Drosera, Phytochemistry, Naphthoquinones, Chemotaxonomy, Micro-morphology, Trichomes, Emergences.

\section{Introduction}

The northern, tropical part of Australia is inhabited by numerous sundew species, of which most are endemic (Brewer \& Schlauer 2018). In northernmost Western Australia and the Northern Territory these species predominantly belong to Drosera sections Lasiocephala Planch. (D. banksii, D. subtilis, and the "D. petiolaris group" or "woolly sundews") and Arachnopus Planch. (the "D. indica group"), while in northern Queensland a further section (D. sect. Prolifera C.T.White, the "rainforest sundews") of species with rosetted sessile (D. adelae F.Muell. and D. schizandra Diels) or petiolate leaves (D. prolifera C.T.White) adds to this diversity. Drosera sect. Prolifera is closely related to D. sect. Arachnopus (Rivadavia et al. 2003; Fleischmann et al. 2018a) but the plants are perennial and they prefer shaded or even forested situations at colline (200-500 m alt.) to montane (500-1000 m alt.) elevations, while the "Indian sundews" are annuals of sunny, usually lowland places. The distributional ranges of the three species of $D$. sect. Prolifera are geographically well separated from each other, and no native hybrids are known. Nevertheless, the artificial hybridization of D. prolifera and D. schizandra was successfully performed by Kamil Pasek in the Czech Republic. Unfortunately, the hybrid has not been described formally, so no cultivar name was established (it is, however, commonly on sale under the informal name "Andromeda").

The acetogenic naphthoquinones, plumbagin ( $\mathrm{P}$ in this paper) and ramentaceone (7-methyljuglone, $\mathrm{M}$ in this paper), are important chemotaxonomic markers in sundews (Drosera L., Culham \& Gornall 1994; Schlauer et al. 2017, 2018). The Queensland sundews have been screened for their naphthoquinones before (Culham \& Gornall 1994) but the chemical diversity within the group has prompted our investigation of the hybrid and, subsequently, a re-evaluation of the published data. Additionally, the close relationship of the Queensland sundews with the "Indian sundews", which are known for their rich diversity of leaf and stem surface emergences (Schlauer et al. 2017, 2018), has made a micromorphological re-investigation ( $c f$. Seine \& Barthlott 1994) of Drosera sect. Prolifera worthwhile.

\section{Materials and methods}

The plants used in the present study were purchased from Thomas Carow (Nüdlingen, Germany), and from Kamil Pasek (Ostrava, Czech Republic), respectively. The methods used were the same as detailed previously (Schlauer et al. 2018). 


\section{Results}

The naphthoquinones detected in the investigated species are summarized in Table 1.

The leaf surface micromorphology of the Queensland sundews is documented in Figures 1 to 4.

\begin{tabular}{|l|l|l|}
\hline \multicolumn{3}{|l|}{$\begin{array}{l}\text { Table 1. Taxa investigated and quinones detected in the present study. } \mathrm{M}=\text { 7-methylju- } \\
\text { glone (and shinanolone); } \mathrm{P}=\text { plumbagin (and isoshinanolone). }\end{array}$} \\
\hline \multicolumn{1}{|c|}{ Taxon } & \multicolumn{1}{c|}{ Quinone(s) } & \multicolumn{1}{c|}{ Reference/Remark } \\
\hline Drosera adelae & $\mathrm{M}$ & confirms Culham \& Gornall (1994) \\
\hline D. prolifera & $\mathrm{P}$ & confirms Culham \& Gornall (1994) \\
\hline D. prolifera $\times$ schizandra & $\mathrm{M}+\mathrm{P}$ & new (this study) \\
\hline D. schizandra & $\mathrm{M}$ & $\begin{array}{l}\text { Culham \& Gornall (1994) did not detect quinones } \\
\text { in this taxon. }\end{array}$ \\
\hline
\end{tabular}

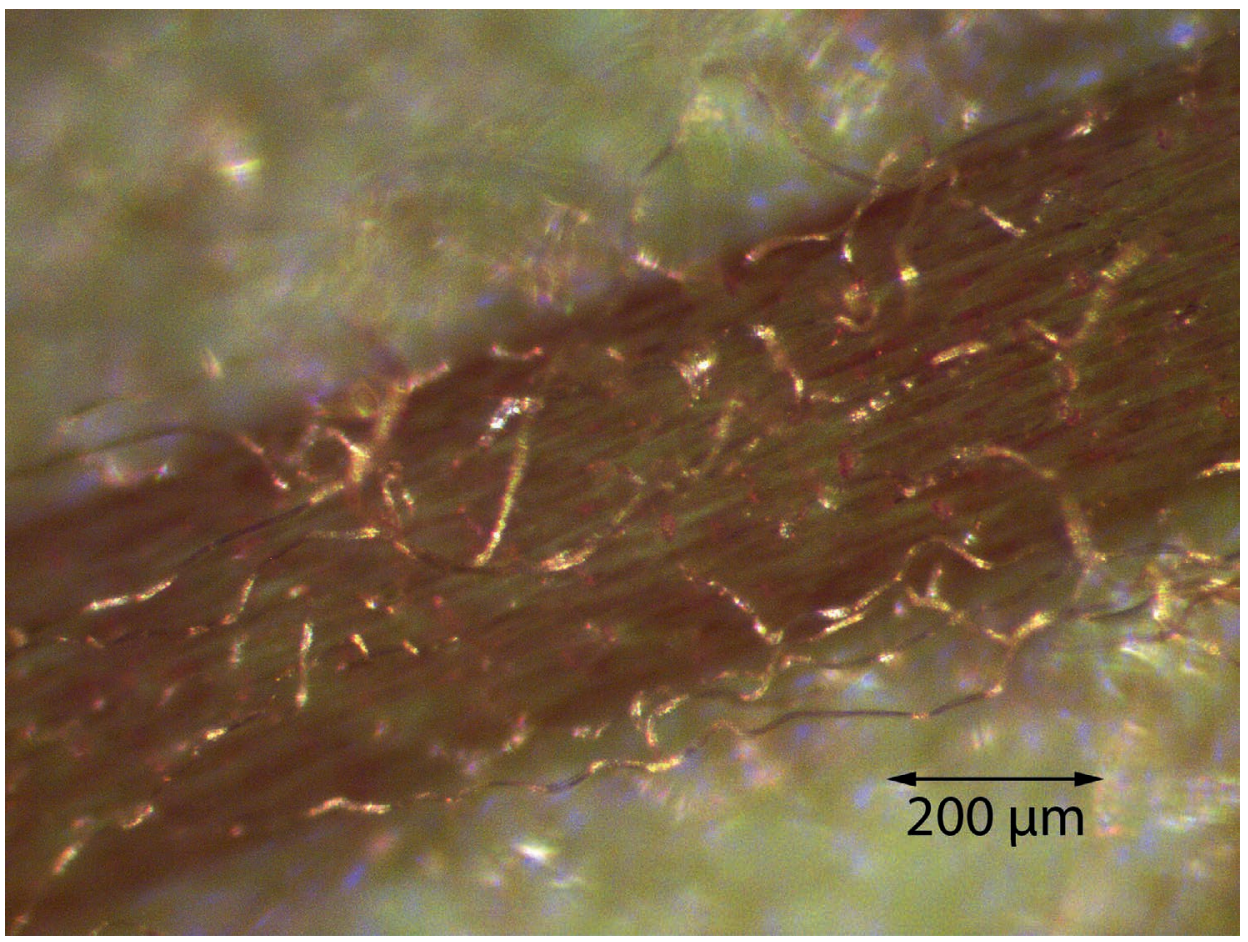

Figure 1: Drosera adelae. Lower leaf surface with many long, occasionally branched (dendritic) woolly trichomes and stipitate and sessile small glands. Photo: S. Hartmeyer. 


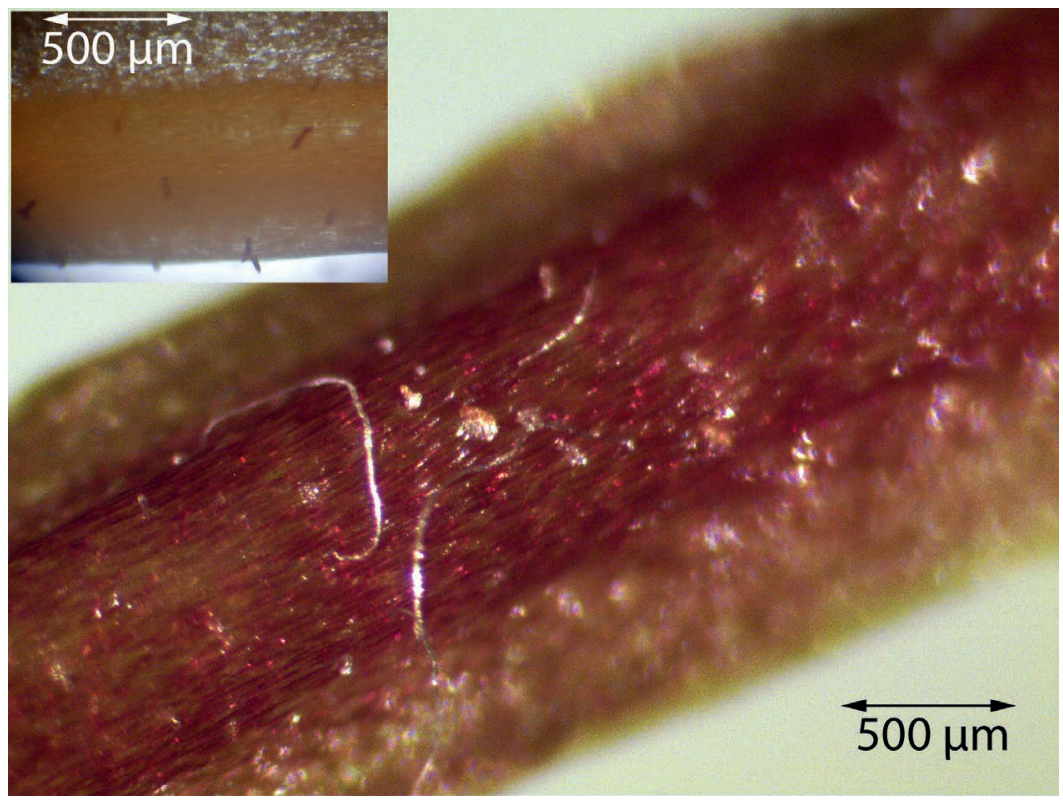

Figure 2: D. prolifera. Petiole with sparse long, woolly trichomes and sessile small glands. Insert: short biseriate trichomes consisting of ca. 10 globular (glandular?) cells. Photo: S. Hartmeyer; insert: J. Schlauer.

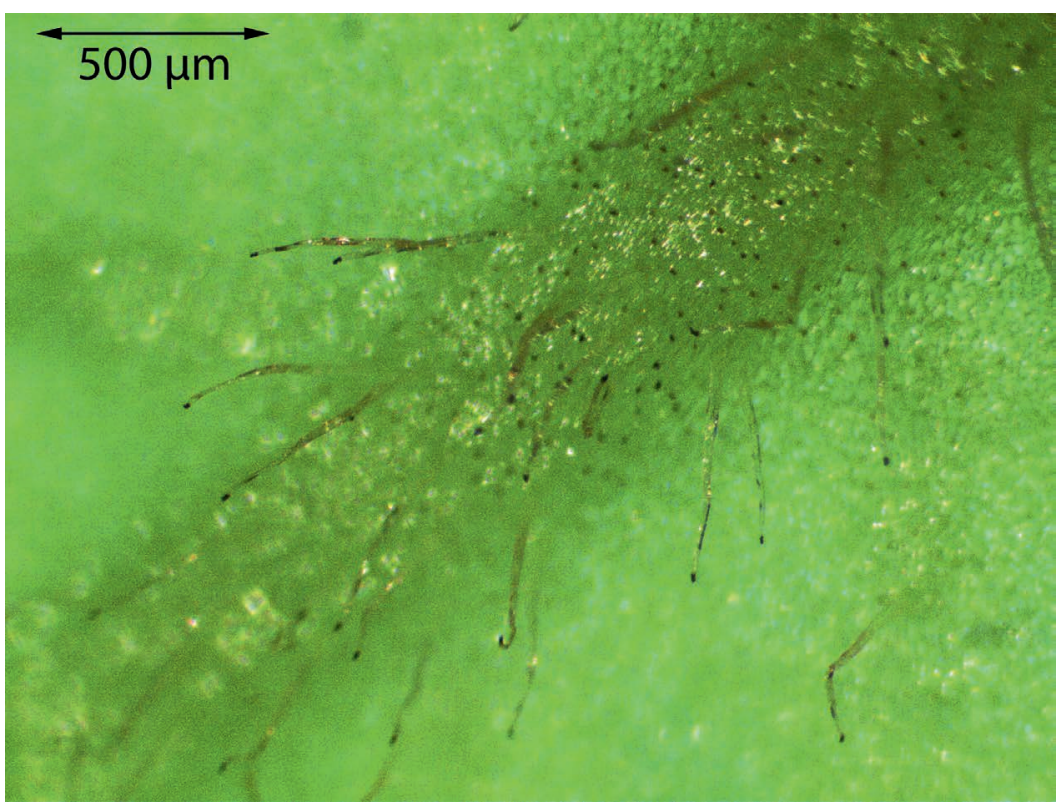

Figure 3: D. schizandra. Lower leaf surface with many long multiseriate glandular trichomes and sessile small glands. Photo: S. Hartmeyer. 


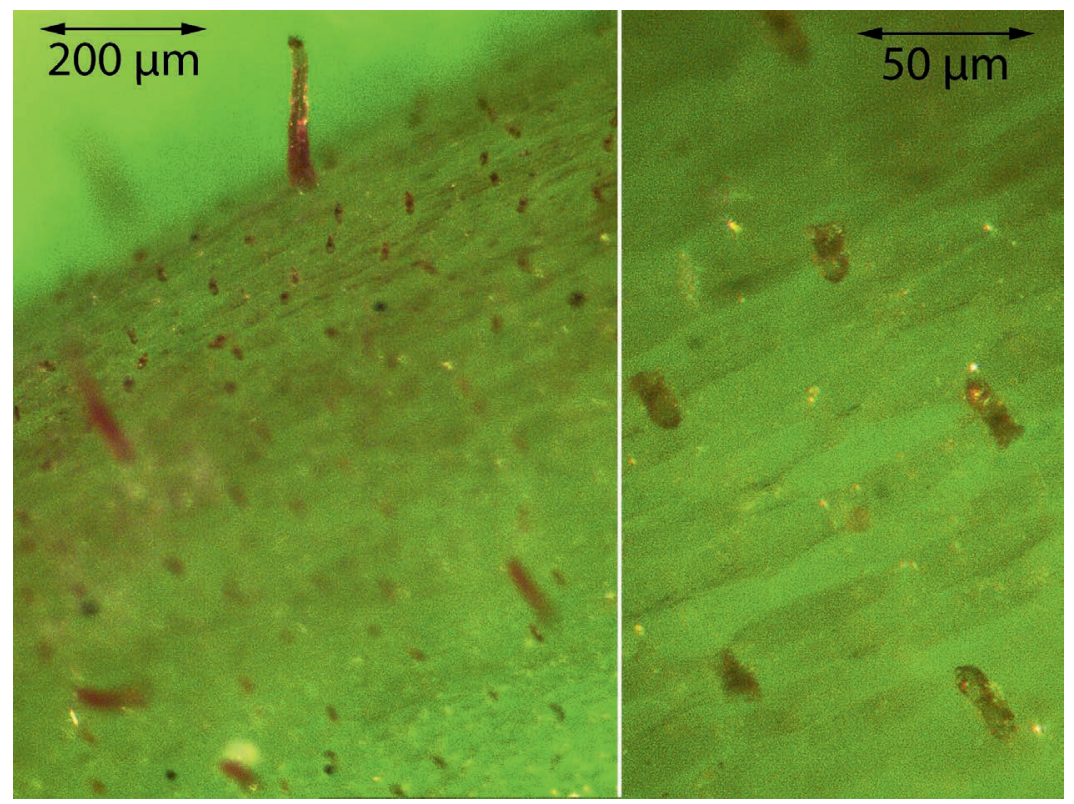

Figure 4: D. prolifera x schizandra. Left: stipitate glands with multiseriate stalk and short biseriate trichomes consisting of ca. 10 globular cells; Right: short biseriate trichomes at higher magnification. Photos: S. Hartmeyer.

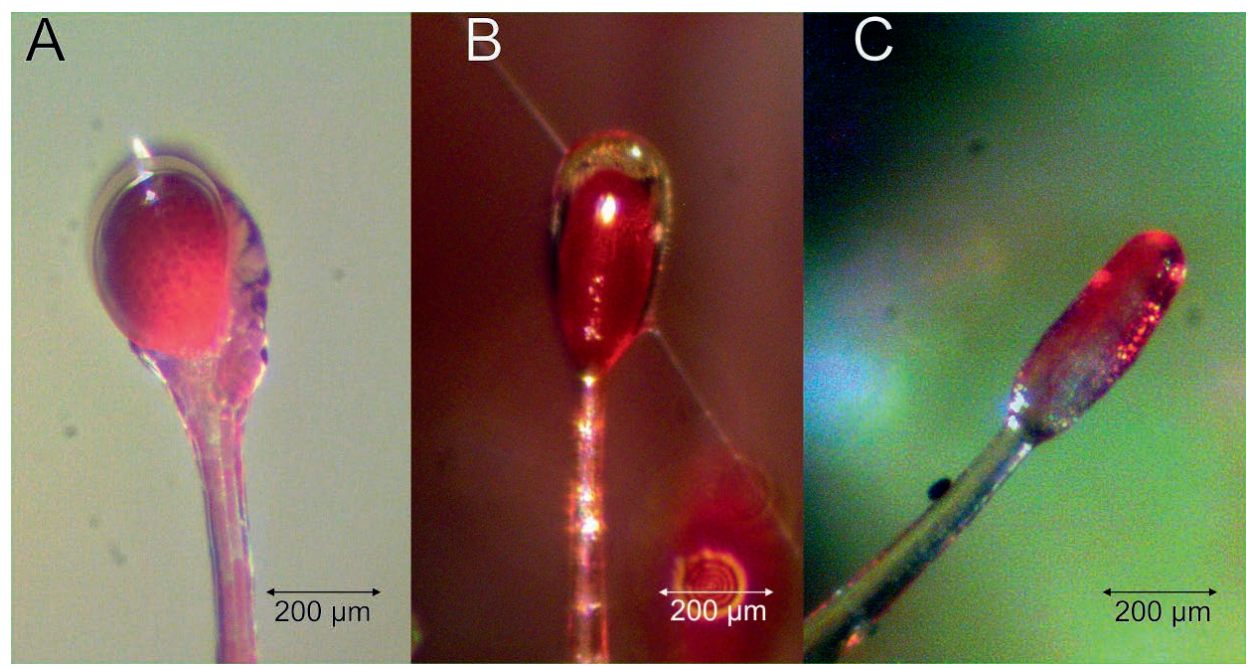

Figure 5: $A=D$. prolifera bilaterally symmetric marginal tentacle (with mucilage); $B=$ $D$. prolifera $x$ schizandra bilaterally symmetric marginal tentacle (mucilage removed for better visibility of gland); $\mathrm{C}=D$. prolifera $\times$ schizandra transitional marginal tentacle (mucilage removed). Photos: S. Hartmeyer. 
Although only four accessions have been investigated in the present study, a number of noteworthy or even outright unexpected results have been obtained.

\section{Naphthoquinones}

The first surprise was the mixture of compounds $(\mathrm{M}+\mathrm{P})$ in the hybrid, in spite of the reported (Culham \& Gornall 1994) absence of quinones in one of the parents (D. schizandra) and the presence of only one isomer $(\mathrm{P})$ in the other parent (D. prolifera). However, our re-investigation of $D$. schizandra revealed it to contain $\mathrm{M}$ (and confirmed $\mathrm{P}$ in D. prolifera and $\mathrm{M}$ in $D$. adelae), which readily explains the quinone pattern of the hybrid, as the simultaneous presence of both isomers has been found in a number of hybrids between quinone-heterogenous parents (Schlauer \& Fleischmann 2016). This also demonstrates that it may be useful to look for quinones in taxa that have not yielded any in previous tests. The production of quinones may be compromised by factors like growing conditions and developmental stage. So, the absence of metabolites does not necessarily constitute a reliable chemotaxonomical character, whereas the presence of specific naphthoquinones (and/or biogenetically related tetralones, Schlauer et al. 2018) is usually reproducible and taxonomically informative in sundews.

With the data now available it can be concluded that the two southern (south of Cairns) species D. adelae and D. schizandra (both containing M) with sessile leaves and non-proliferous scapes, are also chemically more closely related to each other than to the northern (north of Cairns) D. prolifera (that contains P) with distinctly petiolate leaves and with a "trailing" habit (new plantlets being produced from the tip of the scapes), while the affinities throughout $D$. sect. Prolifera are still close enough to allow hybridization.

Like the South Gondwanan D. sect. Psychophila (D. uniflora: M, D. stenopetala: M+P, Schlauer et al. 2019a \& b) this small section displays a quinone diversity similar to its more species-rich relatives, D. sections Arachnopus, Drosera, Ptycnostigma, and Brasilianae.

\section{Surface Micromorphology}

The woolly trichomes of $D$. adelae (incomprehensibly not reported by Seine \& Barthlott 1994) are reminiscent of similar trichomes in Drosera sect. Lasiocephala, in which especially D. ordensis, D. lanata, and D. derbyensis are notable for a particularly rich indumentum (Kondo 1984; Lowrie 1996). Similar trichomes are, however, also known from $D$. sect. Brasilianae ( $D$. graminifolia, D. villosa, Fleischmann et al. 2018b) or D. sect. Drosera (D. neocaledonica, with shorter, stiffer hairs, Seine \& Barthlott 1994; Schlauer et al. 2019a), that are phylogenetically more closely related to $D$. sect. Prolifera.

The long glandular trichomes of $D$. schizandra are obviously inherited (but with a shorter stalk and less numerous) in the hybrid with D. prolifera, while the latter contributes its unique short trichomes (Seine \& Barthlott 1994) that are apparently glandular throughout their length.

In spite of the close phylogenetic relationship between $D$. sect. Prolifera and D. sect. Arachnopus there is little similarity in the indumentum between the two sections. Few if any surface excrescences (except the tentacles) in D. sect. Prolifera are actually emergences (with at least one strand of nonepidermal cells participating in the formation of the stalk), while even non-glandular hair-like structures (like in D. aquatica and D. nana, Schlauer et al. 2018, 2019a) are emergences in D. sect. Arachnopus.

Bilaterally symmetric marginal tentacles (with the gland on the adaxial side) that are present in D. prolifera (Seine \& Barthlott 1994; Fig. 5 A) have never been observed in D. sect. Arachnopus. In 
D. prolifera $\times$ schizandra bilaterally symmetric marginal tentacles (or transitional forms with just a slightly oblique gland, Fig. 5 B \& C) are occasionally formed but much less frequently so than in $D$. prolifera. They are lacking in D. schizandra, so an intermediate condition (co-dominant inheritance) is seen in the hybrid also in this respect.

Acknowledgements: We thankfully appreciate the useful comments and corrections by Andreas Fleischmann and three anonymous reviewers, which have helped to improve this text.

\section{References}

Brewer, S.J., and Schlauer, J. 2018. Biogeography and habitats of carnivorous plants. In: Ellison, A.M., and Adamec, L. (eds.): Carnivorous Plants: Physiology, Ecology, and Evolution. Oxford University Press, pp. 7-21.

Culham, A., and Gornall, R.J. 1994. The taxonomic significance of naphthoquinones in the Droseraceae. Biochem. Syst. Ecol. 22: 507-515.

Fleischmann, A., Cross, A.T., Gibson, R., Gonella, P.M., and Dixon, K.W. 2018a. Systematics and evolution of Droseraceae. Biogeography and habitats of carnivorous plants. In: Ellison, A.M., and Adamec, L. (eds.): Carnivorous Plants: Physiology, Ecology, and Evolution. Oxford University Press, pp. 45-57.

Fleischmann, A., Gonella, P.M., and Rivadavia, F. 2018b. A new sectional name for the Brazilian tetraploid clade of Drosera subgenus Drosera. Carniv. Pl. Newslett. 47: 4-9.

Kondo, K. 1984. Three new species of Drosera L. from Australia. Boletim da Sociedade Broteriana ser. 2, 57: 51-60.

Lowrie, A. 1996. New species in Drosera section Lasiocephala (Droseraceae) from tropical northern Australia. Nuytsia 11: 55-69.

Rivadavia, F., Kondo, K., Kato, M., and Hasebe, M. 2003. Phylogeny of the sundews, Drosera (Droseraceae), based on chloroplast $r b c L$ and nuclear $18 \mathrm{~S}$ ribosomal DNA sequences. Amer. J. Bot. 90: 123-130.

Schlauer, J., and Fleischmann, A. 2016. Chemical evidence for hybridity in Drosera (Droseraceae). Biochem. Syst. Ecol. 66: 33-36.

Schlauer, J., Hartmeyer, S.R.H., and Hartmeyer, I. 2017. Unexpected discovery of 7-methyljuglone (ramentaceone) in several Australian sundews. Carniv. Pl. Newslett. 46: 20-22.

Schlauer, J., Hartmeyer, S.R.H., Hartmeyer, I., Hennern, H., and Hennern, A. 2018. Sundew chemistry and emergence updates. Carniv. Pl. Newslett. 47: 10-17.

Schlauer, J., Hartmeyer, S.R.H., Hartmeyer, I., Hennern, H., and Hennern, A. 2019a. New sundew quinone and emergence data. Carniv. Pl. Newslett. 48(1): 6-12.

Schlauer, J., Carow, T., and Fleischmann, A. 2019b. Quinones from "Gondwanan" sundews. Carniv. Pl. Newslett. 48(1): 13-17.

Seine, R., and Barthlott, H. 1994. On the morphology of trichomes and tentacles of Droseraceae Salisb. Beitr. Biol. Pfl. 67: 345-366. 